Int. J. Dev. Biol. 52: 389-396 (2008)

doi: $10.1387 / \mathrm{ijdb} .072514 \mathrm{jd}$

\title{
Expression and comparative genomics of two serum response factor genes in zebrafish
}

\author{
JODY L. DAVIS ${ }^{1, \#, ~ X I A O C H U N ~ L O N G ~}{ }^{2, \#, ~ M A R Y ~ A . ~ G E O R G E R ~}{ }^{2}$, IAN C. SCOTT $^{3}$, ADAM RICH $^{1}$ \\ and JOSEPH M. MIANO ${ }^{2, *}$ \\ ${ }^{1}$ Department of Biological Sciences, State University of New York College at Brockport, Brockport, NY, \\ ${ }^{2}$ Aab Cardiovascular Research Institute, University of Rochester School of Medicine \& Dentistry, Rochester, NY and \\ ${ }^{3}$ Program in Developmental and Stem Cell Biology, The Hospital for Sick Children, Toronto, ON, USA
}

\begin{abstract}
Serum response factor (SRF) is a single copy, highly conserved transcription factor that governs the expression of hundreds of genes involved with actin cytoskeletal organization, cellular growth and signaling, neuronal circuitry and muscle differentiation. Zebrafish have emerged as a facile and inexpensive vertebrate model to delineate gene expression, regulation, and function, and yet the study of SRF in this animal has been virtually unexplored. Here, we report the existence of two srf genes in zebrafish, with partially overlapping patterns of expression in 3 and 7 day old developing animals. The mammalian ortholog (srf1) encodes for a 520 amino acid protein expressed in adult vascular and visceral smooth muscle cells, cardiac and skeletal muscle, as well as neuronal cells. The second zebrafish srf gene (srf2), encoding for a presumptive protein of only 314 amino acids, is transcribed at lower levels and appears to be less widely expressed across adult tissues. Both srf genes are induced by the SRF coactivator myocardin and attenuated with a short hairpin RNA to mammalian SRF. Promoter studies with srf1 reveal conserved CArG boxes that are the targets of SRF-myocardin in embryonic zebrafish cells. These results reveal that SRF was duplicated in the zebrafish genome and that its protein expression in all three muscle cell types is highly conserved across vertebrate animals suggesting an ancient code for transcriptional regulation of genes unique to muscle cell lineages.
\end{abstract}

KEY WORDS: SRF, myocardin, promoter, muscle

\section{Introduction}

Serum response factor (SRF) is a widely expressed and highly conserved transcription factor that binds to 1,216 permutations of a 10-base pair element known as the CArG box (CamorettiMercado et al., 2003; Miano 2003). A growing number of genes have been shown to contain functional SRF-binding CArG boxes, particularly those encoding for proteins involved with a cell's cytoarchitecture (Minty and Kedes, 1986; Philippar et al., 2004; Zhang etal., 2005; Sun etal., 2006). Representative SRF orthologs have been discovered in all kingdoms except for Monera, and in virtually all cases where SRF has been genetically inactivated, defects in cytoskeletal organization and function have been defined (Miano et al., 2007). Thus, expression of SRF, which arises from a single copy gene in essentially all species, is vital for the mating phenotype in Saccharomyces cerevisae (Elble and
Tye, 1991), cytoskeletal organization and motility in Dictyostelium discoideum (Escalante et al., 2004), animal locomotion in Caenorhabditis elegans (Fukushige et al., 2006), cellular migration and tracheal development in Drosophila melanogaster (Guillemin etal., 1996), and gastrulation in Mus musculus(Arsenian et al., 1998). Further, recent conditional knockout studies in mice have demonstrated a critical role for SRF in the normal organization of the cyto-contractile apparatus in cardiac, skeletal, and smooth muscle cells (SMC) as well as proper neuronal cell migration and cytoarchitecture (Miano et al., 2004; Li et al., 2005; Knöll et al., 2006). These studies all point to a conserved function of SRF in orchestrating programs of gene expression that prima-

Abbreviations used in this paper: SMC, smooth muscle cell; SRF, serum response factor.

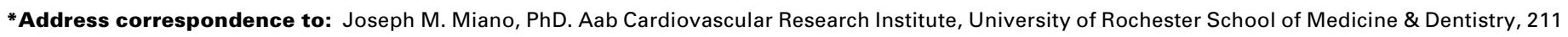
Bailey Road, West Henrietta, New York 14586, USA. Tel: +1-585-276-9789. Fax: +1-585-276-9830. e-mail: j.m.miano@rochester.edu

\#Note: Both authors contributed equally to this work.

Accepted: 24th January 2008 Published online: 14 February 2008. 
rily coordinate a cell's migratory behavior and its cyto-contractile apparatus.

In addition to activating genes involved in appropriate cytocontractile organization and function, SRF is known to induce growth-related genes, including a number of immediate early genes such as c-fos (Norman et al., 1988; Johansen and Prywes, 1995). The ability of SRF to regulate such disparate gene sets as growth and muscle differentiation was an enigma for many years. In 2001, the laboratory of Eric Olson cloned an SRF-associated factor called myocardin (Myocd) (Wang et al., 2001). Myocd is most highly expressed in cardiac and SMC where its encoded protein functions, in conjunction with SRF bound CArG elements, as one of nature's most potent coactivators of gene expression (Wang et al., 2001). Subsequent work revealed that Myocd is a component of a molecular switch for the SMC program of reduced growth potential and differentiation (Chen et al., 2002), findings that were confirmed by several other labs (Du et al., 2003; Wang etal., 2003; Yoshida et al., 2003; Milyavsky et al., 2007). Further work showed that SRF toggles from regulating growth-related genes to SMC differentiation genes through the mutually exclusive binding of Elk1 (pro-growth) and Myocd (pro-differentiation) to a common interface of SRF (Wang et al., 2004; Zaromytidou et al., 2006). Indeed, the ability of SRF to regulate these and other context-dependent gene sets is related to its association with more than 50 coregulators of gene expression (Miano et al., 2007).

Zebrafish (Danio rerio) has emerged as a popular model organism for the study of gene regulation and function. For example, the study of cardiovascular development and physiology is simplified in zebrafish owing to this animal's external development, its rapid maturation $(24 \mathrm{hr})$, as well as its highly conserved organization of blood vessels (Isogai et al., 2001). Surprisingly little information exists with respect to Srf in zebrafish. Early studies using the beta actin promoter, disclosed the essential nature of a conserved CArG element for optimal transgene expression, implying the existence of Srf in zebrafish (Moav et al., 1993). Subsequent work revealed the presence of a single copy srf allele with expression documented only in early embryonic skeletal muscle (Vogel and Gerster, 1999). We now report the presence of two paralogous srfgenes in zebrafish and provide expression analysis of each paralog in larval and adult tissues. We also show that zebrafish Srf function-

\section{HsaSRF}

DreSrf1

Dresrf2

HsaSRF

DreSrf1

Dresrf2

HsaSRF

DreSrf1 DreSrf2

HsaSRF Dresrf1 Dresrf2

HsaSRF DreSrf1 DreSrf2

HsaSRF DreSrf1 Dresrf2

HsaSRF DreSrf1

HsaSRF DreSrf1

HsaSRF Dresrf1

HsaSRF Dresrf1 ally associates with human myocardin to drive endogenous Srfdependent target genes. Moreover, the promoter of zebrafish srf1 is shown to harbor three CArG elements, including two with high conservation, that appear to function as an ancient code for the autoregulation of this important transcription factor. The discovery of two srfalleles in zebrafish paves the way for functional and expression regulation analyses in this vertebrate animal model.

\section{Results and Discussion}

\section{Two paralogs of srf exist in zebrafish}

In a previous report (Vogel and Gerster, 1999), a single srf cDNA was cloned and found to encode a truncated protein of only 247 amino acids (mammalian SRF proteins are $>500$ amino acids). We now report that the original srf(srf1)is actually a much MLPTQAGAAAALGRGSALGGSLNR------TPTGRPGGGGGTRGANGGRVPGNGAGLGPG
---------------------------- MLGGNGTARGAGRSGNGTGLTPL
MLSSQTGAALSGTGAGKSAVVLGAGLRPGLVRSVPAGMLGGSGAARGGERPGSSGGQGPL
$\star \star \star * \star \star \star$
$\star *$

RLEREAAAAAA------TTPAPTAGALYSGSEGDSESGEEEELGAE------RRGLKRSL QVGRYDDG------------PSVEAVLSGSDGDSDSGDDEESPVPD-----RRGVKRER QAGGMLSGLGIGMPVRFDPDKESPLHGCSGSDADSDSGDEEEQSGPLGDTRRSGGVKRER

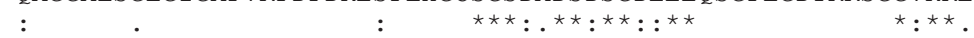

SEMEI GMVVGGPEASAAATGGYGPVSGAVSGAKPGKKTRGRVKIKMEFIDNKLRRYTTFS SELEVGGSSG---SNAALSAGYGGVSSGVAGAKPGKKTRGRVKIKMEFIDNKLRRYTTFS AEMEAALG---AQEAGLPAAGFGVLAGGVAGAKPGKKTRGRVKIKMEFIDNKLRRYTTFS

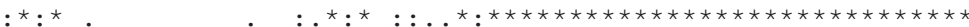

KRKTGIMKKAYELSTLTGTQVLLLVASETGHVYTFATRKLQPMITSETGKALIQTCLNSP KRKTGIMKKAYELSTLTGTQVLLLVASETGHVYTFATRKLQPMITSETGKALIQTCLNSP KRKTGIMKKAYELSTLTGTQVLLLVASETGHVYTFATRKLQPMITSETGKALIQTCLNSP

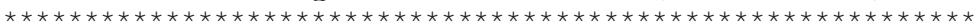

DSPPRSDPTTDQRMSATGFEETDLTYQVSESDS SGETKDTLKPAFTVTNLPGTTSTIQTA DSPPRTDPSTDQRMSATGFEETDLTYQVSEADGLTEPKEMLKPTFTAATLPGGTNTISTT DSPPRSD-CSDQRMSASGYEETELTYQVSESESLGEGKDSLKPVFTVSSLPGSTSATPVT

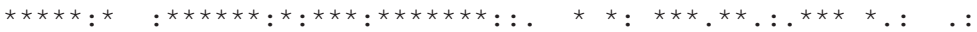

PSTSTTMQVSSGPSFPITN---------YLAPVSASVSPSAVSSANGTVLKSTGSGPVSS TQSPVSSSPSSSSVAMHTQSSGPSLSGTTCWPVAAGMNAQS ISSANGTVLKSS------S

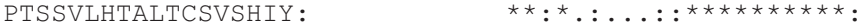
. $\quad: \quad$. .

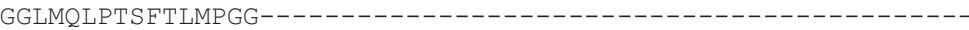
AGMMQLPSGFTLMPGASLPPGTHTVPLSQLQTHSLAIQCPQTQANSSGSTAVPAHTQPAA

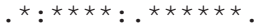

- - - - - - - AVAQQVPVQAIQVHQAPQQASP SRDSSTDLTQTSSSGTVTLPATIMTSS LFRLPAAVSLTGGAMPQQLQAIQVHPSPQSS----DSSPEISQTSSSATASHTATIVTSS

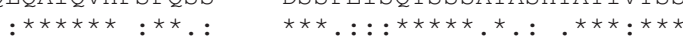

VPTTVGGHMMYPSPHAVMYAPTSGLGDGSLTVLNAFSQAPSTMQVSHSQVQEPGGVPQVF VPSSVAGHMMYPGAHVMYATSTPAFTDGGLTVLSAFPQPPSAMHVSHTTNQDSGGVPQMF

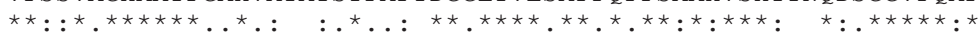

LTASSGTVQI PVSAVQLHQMAVIGQQAGSSS-NLTELQVVNLDTAHSTKSE LTGPPGTVQI PVSAVPLHSMLINQQPSGSSSSTLTELRVVNLDNPKGD

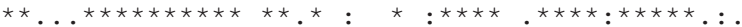

Fig. 1. Amino acid sequence alignment of human and zebrafish Srf proteins. Shown is a ClustalW alignment of the human SRF protein (HsaSRF) with the two zebrafish Srf proteins (DreSrf1 and DreSrf2). Dashes represent gaps, asterisks indicate identical amino acid residues and colons designate conservative amino acid substitutions. The bold amino acid residues represent the dynamically functional MADS domain (Shore and Sharrocks, 1995). The lines above the sequences, GTVQIPVSAV and LTELQ/RVVNLD, indicate probable epitopes recognized by the Santa Cruz polycolonal SRF antibody used in studies shown here in Fig. 4. 


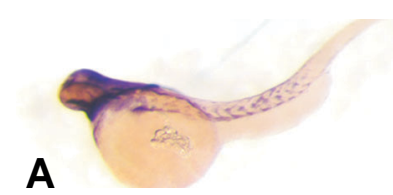

A
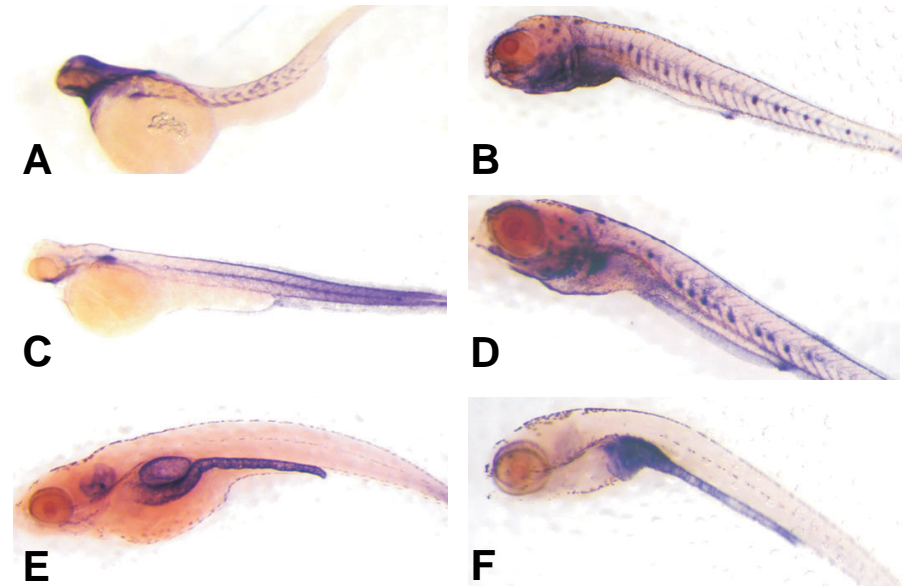

D
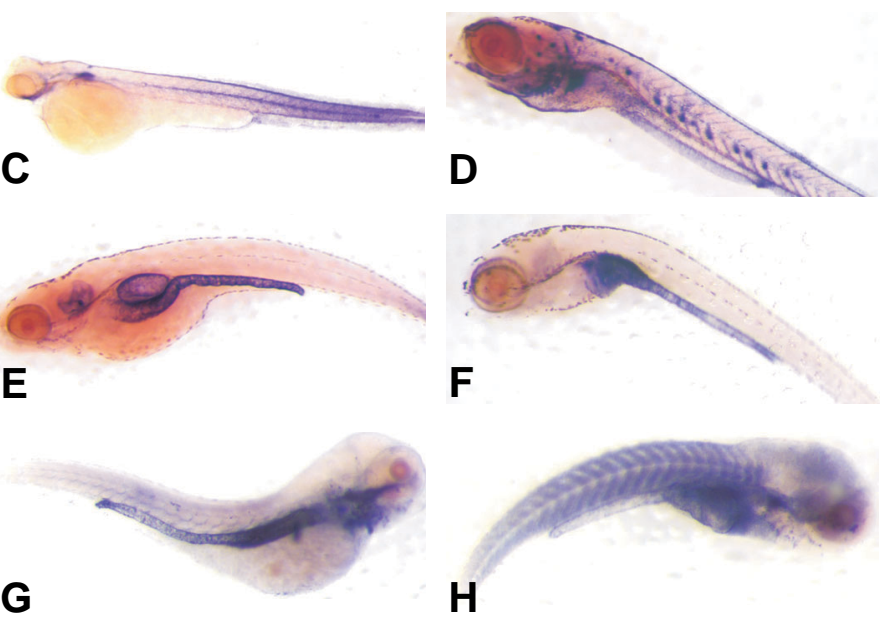

Fig. 2. srf mRNA expression in developing zebrafish. Day $3(\mathbf{A}, \mathbf{C}, \mathbf{E}, \mathbf{G})$ and day $\mathbf{7}(\mathbf{B}, \mathbf{D}, \mathbf{F}, \mathbf{H})$ developing zebrafish embryos/larvae were prepared for whole mount in situ hybridization as described in Materials and Methods with antisense riboprobes to srf1 (A,B), srf2 (C,D), sm22 $\alpha(\mathbf{E}, \mathbf{F})$ and myh11 (G,H). Sections of day 7 larvae validated probe penetrance and sense control probes all showed no staining (data not shown).

longer transcript encoding a 520 amino acid protein (Fig. 1). We discovered that the previously defined, truncated srfarose from a retained intron containing an in-frame stop codon. Srf1 begins 32 residues amino terminal from human SRF (Fig. 1) and has a large block (95 consecutive amino acids) of $100 \%$ amino acid identity encompassing the 56 residue MADS domain (bold residues in Fig. 1), which is the principal functional domain of SRF involved in dozens of protein-protein interactions, self-dimerization as well as DNA binding to CArG elements (Shore and Sharrocks, 1995; Miano et al., 2007). There is also significant homology (59\% amino acid identity over 145 amino acids) in the carboxy-terminal end of Srf1 with human SRF. This region of the protein is considered to have important transactivation activity and can undergo varying degrees of truncation via alternative splicing resulting in natural dominant negative isoforms that mitigate SRFdependent gene activation (Belaguli et al., 1999).

The zebrafish genome underwent duplication more than 100 million years ago and has retained some $25 \%$ of the original duplicated genes (Amores et al., 1998). During the sequence analysis of $s r f 1$, we identified a second, distinct series of overlapping CDNA and EST clones and assembly of these sequences indicated a duplicated srf. srf2 encodes for a protein of only 314 amino acids and, as with Srf1, shares $100 \%$ amino acid identity across the MADS domain of human SRF (Fig. 1). Visual analysis reveals little homology between Srf1 and Srf2 outside the stretch of 95 amino acid identity shared with higher vertebrates (Fig. 1). Extensive database mining has failed to reveal any additional coding sequence to Srf2. The fact that both zebrafish Srf paralogs contain identical MADS domains suggests these proteins could carry out redundant functions. This could explain why there has yet to be any report of a mutant phenotype associated with zebrafish srf.

\section{Zebrafish srf mRNA and protein expression analysis}

To begin evaluating the expression of each zebrafish srfgene, we designed specific riboprobes to interrogate expression during zebrafish development. At three days of development, expression of each srfgene was present predominantly in the developing chevron-shaped somites and this staining persisted through day 7 of development (Fig. 2A-2D). Similar somitic staining was seen at day 7 for the mammalian SRF target gene, myh11(Fig. $2 \mathrm{H})$. We also examined $s m 22 \alpha$ staining as the mammalian ortholog is a known SRF target gene and shows expression in all three muscle lineages during development (Li et al., 1997). In contrast to mammalian studies, but congruent with a recent whole mount zebrafish study (Georgijevic et al., 2007), sm22 $\alpha$ is not seen in developing somites despite the presence of both srf transcripts. On the other hand, abundant expression of sm22 $\alpha$ mRNA (Fig. 2E) and myh11 (Fig. 2G) are observed in the gut, consistent with previous reports (Wallace et al., 2005; Georgijevic et al., 2007).

A number of papers have reported vascular SMC marker expression, including sm22 $\alpha$, in developing SMC of the zebrafish dorsal aorta (Pham et al., 2001; Roman et al., 2002; Yang et al., 2003). We see little evidence of either srf or sm22 $\alpha$ in developing blood vessels of day 3 embryos or day 7 larvae (Fig. 2A-2F). The absence of these SMC markers within the vasculature of such early stage zebrafish is consistent with recent ultrastructural and expression analysis in the developing zebrafish aorta (Miano et al., 2006; Georgijevic et al., 2007). Up to 7 days of development very few SMC are recruited to the dorsal aorta and those present display little evidence of myofilaments or peripheral dense plaques (Miano et al., 2006). Thus, analysis of vascular SMC markers should be done in zebrafish beyond the larval stage of development and will yield the most pertinent information when differentiated vascular SMC fully invest the dorsal aorta by 3 months of age (Miano et al., 2006). At the latter stage of development, we can readily detect $s / 1$ mRNA across multiple tissues by RT-PCR, including female germ cells (Fig. 3). Comparatively lower levels of srf2 mRNA are seen in such tissues as gut and liver with undetectable transcripts in other adult tissues (Fig. 3). Collec-

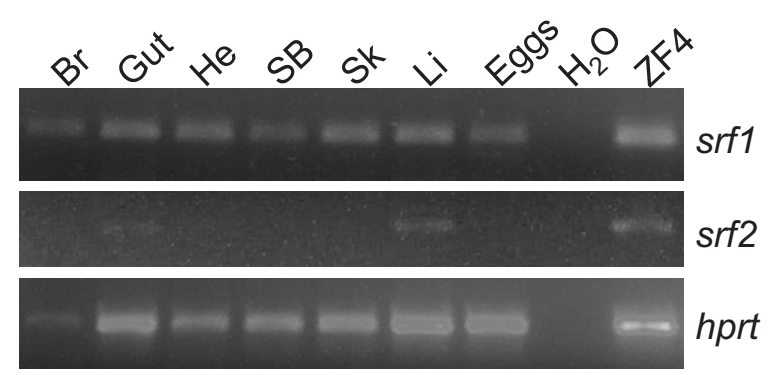

Fig. 3. Adult tissue expression of srf mRNA. Indicated tissues were harvested from 3 month-old zebrafish and cDNA templates prepared with primers specific to each target mRNA as described in Materials and Methods. Abbreviations: Br, brain; He, heart; SB, swim bladder; Sk, skeletal muscle; Li, liver. ZF4 is an embryonic zebrafish fibroblast cell line. hprt is a control mRNA to validate presence of relatively equal amounts of total RNA. These results are representative of two other independent studies. 

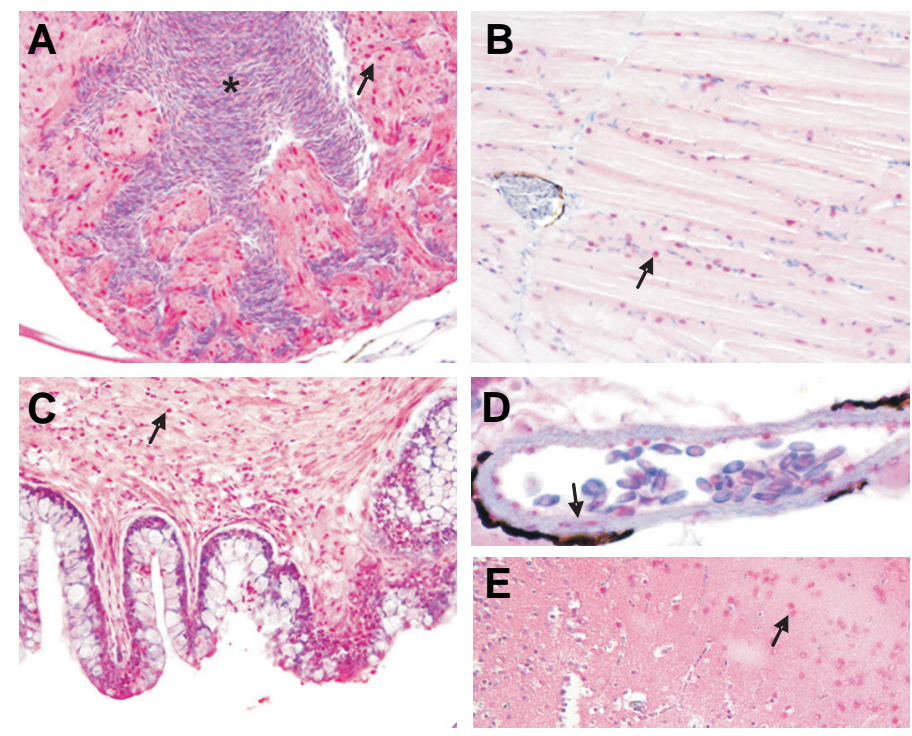

Fig. 4. Adult tissue expression of Srf1 protein. Adult (3 month) tissues were processed for immunohistochemistry as described in Materials and Methods. Arrows point to Srf1 nuclear staining (in red) in cardiomyocytes of the heart (A), skeletal muscle of posterior trunk (B), visceral SMC of gut (C), vascular SMC of dorsal aorta (D) and cortical neurons of brain (E). The asterisk in $(A)$ indicates nucleated red blood cells within the ventricular chamber of the heart. Note the peri-aortic melanin (dark staining rim in panel D) that has recently been described and validated (Miano et al., 2006). Staining specificity was demonstrated with a competing peptide to human SRF (data not shown). Magnifications are 400x.

tively, these results reveal both similarities (early somitic) and differences (adult tissue level and distribution) in the mRNA expression of the two srf genes, suggesting perhaps tissuespecific functions for each zebrafish Srf.

We next evaluated Srf protein expression in adult tissues by immunohistochemistry. These results reveal high-level expression of Srf protein in trabecular cardiomyocytes of the heart, skeletal muscle in the trunk, visceral SMC of the gut, vascular SMC of dorsal aorta, and cortical neurons of the brain (Fig. 4). Since the antibody used was raised to the C-terminal 50 amino acids of human SRF and only Srf1 extends to this region of the protein (Fig. 1), we conclude that the immunoreactive protein observed here represents Srf1. It is important to point out that a previous report showing absence of Srf1 protein in cardiac and SMC was constrained to an analysis of only early zebrafish embryos (Vogel and Gerster, 1999). We now report that Srf1 protein is distributed across adult tissues containing each of the three muscle types (cardiac, skeletal and smooth), which is in good agreement with SRF expression in higher vertebrates (Croissant et al., 1996). The adult tissue expression of Srf2 protein will require further analysis with newly constructed antisera that can distinguish between the two paralogous proteins.

\section{Regulation of srf1 and srf2 expression by SRF and myocardin}

The mammalian SRF promoter contains tandem CArG elements that are the targets of SRF auto-regulation (Spencer and Misra, 1996; Belaguli et al., 1997) and induction by Myocd (Chow et al., 2007). To begin evaluating the expression regulation of each zebrafish sif gene, we used adenoviral gene transfer of human MYOCD and a short-hairpin RNA to mammalian Srf (shSrf) in cultured ZF4 cells, an immortalized zebrafish cell line (see Materials and Methods). Previous studies from this lab have established the utility of these reagents in modulating SMC marker expression (Streb and Miano, 2005; Chow et al., 2007). We note slight down-regulation of both sif mRNAs with shSrf, despite the presence of a 1 bp mismatch between human and zebrafish srfmRNA target sequences. Conversely, increases in both srf transcripts are seen with human MYOCD transduction (Fig. 5). Importantly, we also observe MYOCD-mediated increases in the endogenous smooth muscle myosin heavy chain (myh11) mRNA consistent with this gene's regulation by SRF in higher vertebrates (Manabe and Owens, 2001). These results suggest that both zebrafish Srf proteins can interact with human MYOCD to drive Srf-dependent gene expression and both are subject to silencing with shRNA targeted to mammalian SRF.

To determine whether functional CArG elements are present in srf, we cloned the srf1 promoter; extensive database mining failed to reveal reliable srf2 promoter sequence. Figure $6 \mathrm{~A}$ shows that the 5' promoter region of srf1 contains two CArG elements $(C 1-C 2)$ separated by 13 base pairs, a distance that is very close to the 10 base pairs separating all known tandem CArGs within Srf promoters in higher animals. Moreover, the distance of the srf1 tandem CArG elements from the start site of transcription is in close agreement with that of other vertebrates. An analysis of Srf promoters from the genomes of cat, chicken, cow, dog, human, monkey, mouse, opossum, and rat reveals that $\mathrm{C} 1$ (ccatataagg) has virtually $100 \%$ sequence identity; only chicken Srf, with its $\mathrm{C} 1$ element being ccttataagg deviates from this consensus. The C2 CArG box diverges slightly more across the 10 vertebrates studied with base pair substitutions in 5/10 sequences across the CArG box. These comparative genomic data, summarized in Figure 6B as a sequence logo, indicate a high degree of CArG sequence conservation among Srf promoters. Note that the zebrafish srf1 promoter has a third CArG box (C3), which is not present in

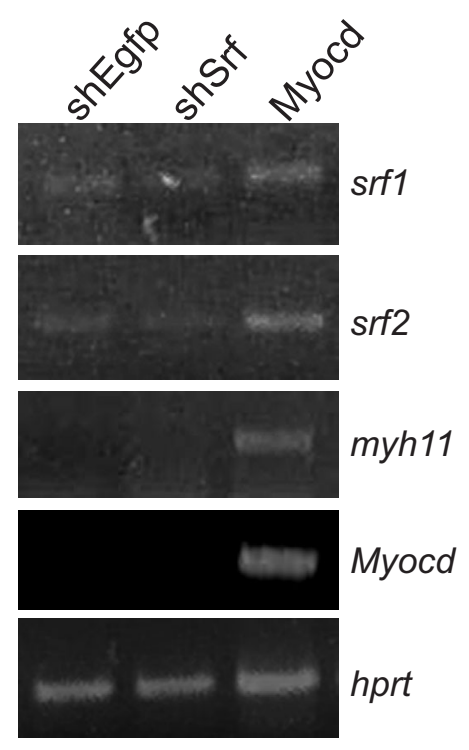

Fig. 5. Modulating endogenous Srf genes. Expression of srf1 and srf2 genes was studied in the ZF4 embryonic zebrafish fibroblast cell line following transduction with the indicated adenoviral transgenes. Total RNA was isolated for RT-PCR three days post-viral transduction. Note attenuated expression of both srf transcripts with shRNA to mammalian Srf and increases with a human MYOCD transgene. Increases in endogenous myh11 la known mammalian SRF target gene restricted only to SMC lineages; Miano et al., 1994) are also evident with Ad-MYOCD. As in Fig. 3, the hprt housekeeping gene serves as a loading control. Results were repeated in an independent study. 
Fig. 6. Cloning and functional analysis of the srf1 promoter. (A) Sequence of coding region (in capital letters with ATG translation start site in bold) and $5^{\prime}$ promoter of srf1. Numbering at left reflects the position of each nucleotide relative to the annotated transcription start site (designated as +1). The three CArG elements are indicated by the boxed sequences and are labeled C1-C3. Lines above or below sequences indicate, respectively, forward and reverse primers for the PCR amplification of srf1 promoter. (B) A sequence logo from 10 vertebrate SRFCArGs (see text) representing the frequency in which each base across species occurs over the 10 base pair CArG box. The higher conservation of $\mathrm{C} 1$ (ccatataagg, at left) is indicated by fewer base substitutions across the CArG element (compare with C2, at right).

The intervening region between these CArGs (noted as base pairs 11 and 12) is not to scale because slight deviations in length (from 10 in mammals to 13 in fish) exist across species. (C) Cos-7 cells co-transfected with empty vector or SRF-VP16 and either the full length, wildtype srf1 promoter (WT, shown in panel A) or srf1 promoters containing the indicated mutant (mut) CArG elements (abbreviated C1-C3). Data represent normalized luciferase (to Renilla control). (D) The same study as in panel (C) only the cell type is PAC1 SMC and the activator is Myocardin. (E) ZF4 cells cotransfected with empty vector or Myocardin and either WT or triple CArG mutant srf1 promoter. Note the different ordinate scales in the basal (left) versus Myocd-induced (right) studies. All promoter transfection data are representative of two independent studies with three replicates per study. Statistically significant differences $(p<0.05)$ were detected for all paired data except for the mutC1-C3 condition in panel (D).

other animal species (Fig. 6A).

To begin appraising the srf 1 promoter in a functional assay, we transfected various cell lines with wildtype or CArG mutant srf1 promoter constructs linked to a luciferase reporter gene in the presence or absence of Myocd or an SRF-VP16 transactivator and measured the resultant luciferase activity. Results in mammalian cells reveal both SRF-VP16-and Myocddependent activation of the srf1promoter. Mutations in each of the three $\mathrm{CArG}$ elements reduced basal and induced promoter activities, with the most dramatic decreases seen when the two conserved $\mathrm{CArG}$ elements ( $\mathrm{C} 1-\mathrm{C} 2)$ were mutated together with C3 (Figs. 6C-D). Mutations in all three CArG boxes also blunted both basal and Myocd-activated srf1 in the ZF4 cell line (Fig. $6 \mathrm{E})$. Collectively, the results indicate that vertebrate Srf promoter CArG elements (particularly C1) appear to function as an ancient code for SRF-mediated auto-regulation and SRF-dependent target gene expression control. An important future goal should be to ascertain the role of Srf1/2 in regulating expression of SMC markers expressed in zebrafish such as myh11 (Wallace et al., 2005), sm22 $\alpha$ and the SMC isoforms of alpha actin (Georgijevic et al., 2007) and calponin. In addition, it may prove effective to evaluate mammalian Srf regulatory elements in zebrafish given similar tissue expression profiles and the ease in which such analyses can be done in this model organism.

\section{Materials and Methods}

\section{Aquaculture and cell lines} previously (Rich et al., 2007). Wild-type adult zebrafish were obtained from the Zebrafish International Resource Center and were maintained according to standard guidelines in accordance with IACUC guidelines (Westerfield 2000). Fish were maintained at $28^{\circ} \mathrm{C}$ in deionized water containing $240 \mathrm{mg} / \mathrm{L}$ of Instant Ocean Salts and $75 \mathrm{mg} / \mathrm{L} \mathrm{NaHCO}_{3}$ with 20 $\%$ system water change each day $(\mathrm{pH}$ and conductivity were adjusted to approximately 7.2 and 450 ppm respectively). Zebrafish were fed three times daily, alternating Cyclopeeze (Argent, Redmond, WA) with live brine shrimp. The cycle of light and dark was 14-hr light followed by 10$\mathrm{hr}$ dark. Embryos and larvae (3 and 7-day old) were obtained from Aquatica Tropicals (Plant City, FL) and were cared for in accordance with an approved IACUC protocol. Addition of $1.5 \mathrm{mM}$ 1-phenyl-2-thiourea (PTU) to E3 media was used to prevent pigmentation of embryos from 24 hrs to the 7 day larval stage without obvious toxicity.

The ZF4 embryonic zebrafish cell line (Driever and Rangini, 1993) was obtained from American Type Culture Collection and grown at $28^{\circ} \mathrm{C}$ in a 1:1 mixture of DMEM/Ham's F-12 supplemented with $10 \%$ FBS and Lglutamine without antibiotics or antimycotics. The PAC1 SMC line
Zebrafish were obtained and cared for following methods described 
(Rothman et al., 1992) was grown at $37^{\circ} \mathrm{C}$ in DMEM supplemented with $10 \%$ FBS and L-glutamine without antibiotics or antimycotics. PAC1 SMC express most SMC markers and are an ideal culture model for studying SMC differentiation (Firulli et al., 1998). We did not test for mycoplasma in either of the cell lines used.

\section{Cloning of zebrafish srf cDNAs and srf1 promoter}

We initially designed the following primers to a suspected zebrafish srf ortholog: ctggatctaacgccgcactctcg (forward) and tgagtcctgattcgttgtgtgcga (reverse) and sequence analysis of the PCR product confirmed high-level conservation with human and rodent Srf orthologs across the MADS domain (see below). During the course of our work, we became aware of a potential second zebrafish srfgene and trace archiving combined with cDNA cloning confirmed the srf2 allele. All sequence analysis was done through the University of Rochester's Functional Genomics Core coupled with the NCBI's workstation and the Accelrys Genetics Computer Group's software package (Version 11.1; San Diego, CA). ClustalW analysis was done to align the primary amino acid sequences of the two zebrafish Srf proteins with human SRF (http://www.ch.embnet.org/software/ ClustalW.html). The sequences to both zebrafish srfparalogs are now available in the NCBI database (srf1:BC050480; srf2.BC057414).

The srf1promoter was found within a genomic contig (NW_001512469) and the presumptive start site of transcription inferred from 5' RACE and EST data mining. Primers used to amplify the srf1 promoter were aacggagtagcgcatcatttgca (forward) and tctgtgcagcagatcccagatcaa (reverse). Sequence logos (http://weblogo.berkeley.edu/) of the tandem srf1 $\mathrm{CArG}$ elements were generated based on comparative genomics among 10 orthologous vertebrate serum response factor promoters.

\section{Total RNA isolation and RT-PCR analysis}

Total RNA was isolated from freshly dissected adult wild-type zebrafish organs including brain, heart, gut, swim bladder, skeletal muscle, liver, and eggs using TRIzol extraction. First-strand cDNA synthesis was carried out using $4 \mu \mathrm{g}$ total RNA with a First-Strand cDNA synthesis kit (Amersham Biosciences, Piscataway, NJ). PCR was performed using 1 $\mu \mathrm{g}$ of the First-Strand reaction mixture, Platinum PCR Supermix (Invitrogen, Carlsbad, CA) and oligonucleotide primers to either

srf1

forward: acggtggtcgtaaagggctagttt; reverse: tagaggtgtcaatcccgtgccatt, sif2

forward: atgctgtccagtcagaccggagc; reverse: aggtggtgtatctccgcagtttgt, or hprt

forward: atcatggaccgaactgaacgtctggc; reverse: tgtggtttaaatctctaaagtactcg, which served as an internal, house-keeping control. PCR conditions were a 2 minute hot start at $95^{\circ} \mathrm{C}$ followed by 31 cycles of $95^{\circ} \mathrm{C}$ for $30 \mathrm{sec}, 58^{\circ} \mathrm{C}$ for $30 \mathrm{sec}$, and $72^{\circ} \mathrm{C}$ for $45 \mathrm{sec}$ and a final 7 minute polishing step at $72^{\circ} \mathrm{C}$. For adenoviral transfer studies, ZF4 cells were grown in medium and transduced with adenovirus containing shRNA to mammalian SRF (AdshSRF; target sequence is acgggcatcatgaag with the bold-underlined base the only mismatch in both zebrafish srfmRNAs), Ad-shEGFP, or AdMYOCD under the control of a CMV promoter as described (Streb and Miano, 2005; Chow et al., 2007) and then total RNA isolated 3 days later. Primers specific to zebrafish myh11 (SMC myosin heavy chain) were aaccctaactttccaaatcgcggc (forward) and aggcgttgtccgtgatggaataga (reverse) and primers to srf1, srf2, and hprt were as described above. Primers to human MYOCD were tttcagaggtaacacagcctccatcc (forward) and actgtc ggtggcatagggatcaaaa (reverse). All amplification products were resolved in a $1.5 \%$ agarose gel and sequencing confirmed the identity of each PCR amplified product. Results were repeated in at least one independent experiment.

\section{Whole mount in-situ hybridization}

Whole mount in situhybridization (ISH) was performed in accordance with previously published techniques (Westerfield 2000; Scott et al., 2007). Briefly, antisense and sense control RNA probes specific to srf1 and srf2were made using a Digoxigenin probe labeling kit (Roche). These probes were generated with the same primers listed above for RT-PCR encompassing nucleotides 51-388 (srff) and nucleotides 152-677 (srf2); both probes are $\mathrm{N}$-terminal to the highly conserved MADS domain. Embryos and larvae were fixed in $4 \%$ para-formaldehyde at $4^{\circ} \mathrm{C}$, washed with phosphate buffered saline (PBS) and dehydrated in methanol at $20^{\circ} \mathrm{C}$. Prepared embryos/larvae were re-hydrated, step-wise, and then digested with Proteinase $\mathrm{K}$ to improve permeability for probe penetration. The hybridization solution was added and incubated at $70^{\circ} \mathrm{C}$ for 1 hour before addition of $150 \mathrm{ng}$ probe and continued incubation overnight at $70^{\circ} \mathrm{C}$. The probe was removed through several washes at $70^{\circ} \mathrm{C}$ and then PBSTw containing $5 \%$ heat inactivated sheep serum was added as a blocking agent. Detection of probe was carried out by adding antiDigoxigenin (Alkaline Phosphatase conjugated) in PBSTw/sheep serum $(1: 5000)$ and incubation at $4^{\circ} \mathrm{C}$. Removal of the antibody solution was followed by washes in staining buffer and then staining at RT in the dark in NBT/BCIP (Roche) as described (Scott etal., 2007). When staining was completed the embryos/larvae were washed in PBSTw and then fixed in $4 \%$ para-formaldehyde. Newly washed and dehydrated embryos/larvae were then cleared in benzyl benzoate:benzyl alcohol (2:1) clearing agent and photographed using a Leica MZ125 microscope equipped with a Spot Insight digital camera (Bannockburn, IL).

\section{Immunohistochemistry}

Adult wild-type zebrafish tissues were fixed in $4 \%$ buffered paraformaldehyde, paraffin embedded and cut at 5 micron thickness. All slides were deparaffinized and rehydrated in PBS $(\mathrm{pH}, 7.4)$. Endogenous peroxidase activity was quenched using $3 \%$ aqueous hydrogen peroxide for 10 minutes and antigen retrieval was performed utilizing heat induced epitope retrieval in $0.05 \%$ citraconic anhydride as described (Namimatsu et al., 2005). Srf slides were blocked in 5\% normal goat serum (Vector S100) for 30 minutes then incubated in SRF antibody 1:1200 (Santa Cruz sc-335, Santa Cruz, CA) overnight at $4^{\circ} \mathrm{C}$. This SRF polyclonal antibody was raised to the $\mathrm{C}$-terminal 50 amino acids of human SRF and therefore only detects the Srf1 protein (see Figure 1). The secondary antibody, biotinylated goat anti-rabbit (Vector BA-1000), was used at a dilution of $1: 400$ and applied for 30 minutes at RT. Alkaline phosphatase detection system (Vector AK-5000) was applied for 30 minutes followed by Vector Red chromagen (Vector SK-5100) in the dark for 30 minutes.

\section{Cell transfections and luciferase assay}

ZF4, PAC1, and Cos-7 cells were plated in 24-well plates and grown to $80 \%$ confluency prior to co-transfection with wildtype or various srf1 mutant promoter constructs in the absence or presence of expression plasmids to either Myocd or SRF-VP16. A Renilla plasmid was included in all transfections to normalize raw data for slight variations in cell number, pipeting, and transfection efficiency. Triplicates for each condition were assayed 48 hours post transfection as previously described (Miano et al., 2000) with a Dual Luciferase Assay kit (Promega, Madison, WI). Normalized data were analyzed with GraphPad Prism Software (San Diego, CA, version 4) using paired t-tests for statistical significance. All experiments were repeated at least once in an independent study.

\section{Acknowledgements}

The authors acknowledge the support of the National Institutes of Health (HL-62572 to JMM and DK-07158801 to AR).

\section{References}

AMORES, A., FORCE, A., YAN, Y.-L., JOLY, L., AMEMIYA, C., FRITZ, A., HO, R.K., LANGELAND, J., PRINCE, V., WANG, Y.-L., WESTERFIELD, M., EKKER, M., and POSTLETHWAIT, J.H. (1998). Zebrafish hox clusters and vertebrate genome evolution. Science 282: 1711-1714.

ARSENIAN, S., WEINHOLD, B., OELGESCHLAGER, M., RUTHER, U., and NORDHEIM, A. (1998). Serum response factor is essential for mesoderm 
formation during mouse embryogenesis. EMBO J. 17: 6289-6299.

BELAGULI, N.S., SCHILDMEYER, L.A., and SCHWARTZ, R.J. (1997). Organization and myogenic restricted expression of the murine serum response factor gene: a role for autoregulation. J. Biol. Chem. 272: 18222-18231.

BELAGULI, N.S., ZHOU, W., TRINH, T.-H.T., MAJESKY, M.W., and SCHWARTZ, R.J. (1999). Dominant negative murine serum response factor: alternative splicing within the activation domain inhibits transactivation of serum response factor binding targets. Mol. Cell. Biol. 19: 4582-4591.

CAMORETTI-MERCADO, B., DULIN, N.O., and SOLWAY, J. (2003). Serum response factor function and dysfunction in smooth muscle. Resp. Physiol. Neurobiol. 137: 223-235.

CHEN, J., KITCHEN, C.M., STREB, J.W., and MIANO, J.M. (2002). Myocardin: a component of a molecular switch for smooth muscle differentiation. J. Mol. Cell. Cardiol. 34: 1345-1356.

CHOW, N., BELL, R.D., DEANE, R., STREB, J.W., CHEN, J., BROOKS, A., VAN NOSTRAND, W., MIANO, J.M., and ZLOKOVIC, B.V. (2007). Serum response factor and myocardin mediate arterial hypercontractility and cerebral blood flow dysregulation in Alzheimer's phenotype. Proc. Natl. Acad. Sci., USA 104: 823828.

CROISSANT, J.D., KIM, J.H., EICHELE, G., GOERING, L., LOUGH, J., PRYWES, R., and SCHWARTZ, R.J. (1996). Avian serum response factor expression restricted primarily to muscle cell lineages is required for $\alpha$-actin gene transcription. Dev. Biol. 177: 250-264.

DRIEVER, W. and RANGINI, Z. (1993). Characterization of a cell line derived from zebrafish (Brachydanio rerio) embryos. In Vitro Cell. Dev. Biol. 29A: 749-754.

DU, K., IP, H.S., LI, J., CHEN, M., DANDRE, F., YU, W., LU, M.M., OWENS, G.K., and PARMACEK, M.S. (2003). Myocardin is a critical serum response factor cofactor in the transcriptional program regulating smooth muscle cell differentiation. Mol. Cell. Biol. 23: 2425-2437.

ELBLE, R. and TYE, B.-K. (1991). Both activation and repression of a-mating-typespecific genes in yeast require transcription factor Mcm1. Proc. Natl. Acad. SCi., USA 88: 10966-10970.

ESCALANTE, R., YAMADA, Y., COTTER, D., SASTRE, L., and SAMESHIMA, M. (2004). The MADS-box transcription factor SrfA is required for actin cytoskeleton organization and spore coat stability during Dictyostelium sporulation. Mech. Dev. 121: 51-56.

FIRULLI, A.B., HAN, D., KELLY-ROLOFF, L., KOTELIANSKY, V.E., SCHWARTZ, S.M., OLSON, E.N., and MIANO, J.M. (1998). A comparative molecular analysis of four rat smooth muscle cell lines. In Vitro Cell. Dev. Biol. 34: 217-226.

FUKUSHIGE, T., BRODIGAN, T.M., SCHRIEFER, L.A., WATERSTON, R.H., and KRAUSE, M. (2006). Defining the transcriptional redundancy of early bodywall muscle development in C. elegans: evidence for a unified theory of animal muscle development. Genes Dev. 20: 3395-3406.

GEORGIJEVIC, S., SUBRAMANIAN, Y., ROLLINS, E.L., STAROVIC-SUBOTA, O., TANG, A.C.Y., and CHILDS, S.J. (2007). Spatiotemporal expression of smooth muscle markers in developing zebrafish gut. Dev. Dyn. 236: 1623-1632.

GUILLEMIN, K., GROPPE, J., DÜCKER, K., TREISMAN, R., HAFEN, E., AFFOLTER, M., and KRASNOW, M.A. (1996). The pruned gene encodes the Drosophila serum response factor and regulates cytoplasmic outgrowth during terminal branching of the tracheal system. Development 122: 1353-1362.

ISOGAI, S., HORIGUCHI, M., and WEINSTEIN, B.M. (2001). The vascular anatomy of the developing zebrafish: an atlas of embryonic and early larval development. Dev. Biol. 230: 278-301.

JOHANSEN, F.E. and PRYWES, R. (1995). Serum response factor: transcriptional regulation of genes induced by growth factors and differentiation. Biochim. Biophys. Acta 1242: 1-10.

KNÖLL, B., KRETZ, O., FIEDLER, C., ALBERTI, S., SCHÜTZ, G., FROTSCHER, M., and NORDHEIM, A. (2006). Serum response factor controls neuronal circuit assembly in the hippocampus. Nat. Neurosci. 9: 195-204.

LI, L., LIU, Z.C., MERCER, B., OVERBEEK, P., and OLSON, E.N. (1997). Evidence for serum response factor-mediated regulatory networks governing SM22 $\alpha$ transcription in smooth, skeletal, and cardiac muscle cells. Dev. Biol. 187: 311 321.

LI, S., CZUBRYT, M.P., MCANALLY, J., BASSEL-DUBY, R., RICHARDSON, J.A., WIEBEL, F.F., NORDHEIM, A., and OLSON, E.N. (2005). Requirement for serum response factor for skeletal muscle growth and maturation revealed by tissue-specific gene deletion in mice. Proc. Natl. Acad. Sci., USA 102: 1082 1087.

MANABE, I. and OWENS, G.K. (2001). The smooth muscle myosin heavy chain gene exhibits smooth muscle subtype-selective modular regulation in vivo. J. Biol. Chem. 276: 39076-39087.

MIANO, J.M. (2003). Serum response factor: toggling between disparate programs of gene expression. J. Mol. Cell. Cardiol. 35: 577-593.

MIANO, J.M., CARLSON, M.J., SPENCER, J.A., and MISRA, R.P. (2000). Serum response factor-dependent regulation of the smooth muscle calponin gene. J. Biol. Chem. 275: 9814-9822.

MIANO, J.M., CSERJESI, P., LIGON, K.L., PERIASAMY, M., and OLSON, E.N (1994). Smooth muscle myosin heavy chain exclusively marks the smooth muscle lineage during mouse embryogenesis. Circ. Res. 75: 803-812.

MIANO, J.M., GEORGER, M.A., RICH, A., and DE MESY-BENTLEY, K.L. (2006). Ultrastructure of zebrafish dorsal aortic cells. Zebrafish 3: 455-463.

MIANO, J.M., LONG, X., and FUJIWARA, K. (2007). Serum response factor: master regulator of the actin cytoskeleton and contractile apparatus. Am. J. Physiol. Cell Physiol. 292: C70-C81.

MIANO, J.M., RAMANAN, N., GEORGER, M.A., DE MESY-BENTLEY, K.L., EMERSON, R.L., BALZA, R.O., JR., XIAO, Q., WEILER, H., GINTY, D.D., and MISRA, R.P. (2004). Restricted inactivation of serum response factor to the cardiovascular system. Proc. Natl. Acad. Sci.,USA 101: 17132-17137.

MILYAVSKY, M., SHATS, I., CHOLOSTOY, A., BROSH, R., BUGANIM, Y., WEISZ, L., KOGAN, I., COHEN, M., SHATZ, M., MADAR, S., KALO, E., GOLDFINGER N., YUAN, J., RON, S., MACKENZIE, K., EDEN, A., and ROTTER, V. (2007) Inactivation of myocardin and p16 during malignant transformation contributes to a differentiation defect. Cancer Cel/11: 133-146.

MINTY, A. and KEDES, L. (1986). Upstream regions of the human cardiac actin gene that modulate its transcription in muscle cells: presence of an evolutionarily conserved repeated motif. Mol. Cell. Biol. 6: 2125-2136.

MOAV, B., LIU, Z., CALDOVIC, L.D., GROSS, M.L., FARAS, A.J., and HACKETT, P.B. (1993). Regulation of expression of transgenes in developing fish. Transgenic Res. 2: 153-161.

NAMIMATSU, S., GHAZIZADEH, M., and SUGISAKI, Y. (2005). Reversing the effects of formalin fixation with citraconic anhydride and heat: a universal antigen retrieval method. J. Histochem. Cytochem. 53: 3-11.

NORMAN, C., RUNSWICK, M., POLLOCK, R., and TREISMAN, R. (1988). Isolation and properties of cDNA clones encoding SRF, a transcription factor that binds to the c-fos serum response element. Cel/55: 989-1003.

PHAM, V.N., ROMAN, B.L., and WEINSTEIN, B.M. (2001). Isolation and expression analysis of three zebrafish angiopoietin genes. Dev. Dyn. 221: 470-474.

PHILIPPAR, U., SCHRATT, G., DIETERICH, C., MÜLLER, J.M., GALGÓCZY, P., ENGEL, F.B., KEATING, M.T., GERTLER, F., SCHÜLE, R., VINGRON, M., and NORDHEIM, A. (2004). The SRF target gene Fhl2 antagonizes RhoA/MAL dependent activation of SRF. Mol. Cell16: 867-880.

RICH, A., LEDDON, S.A., HESS, S.L., GIBBONS, S.J., MILLER, S., XU, X., and FARRUGAI, G. (2007). Kit-like immunoreactivity in the zebrafish gastrointestinal tract reveals putative ICC. Dev. Dyn. 236: 903-911.

ROMAN, B.L., PHAM, V.N., LAWSON, N.D., KULIK, M., CHILDS, S., LEKVEN A.C., GARRITY, D.M., MOON, R.T., FISHMAN, M.C., LECHLEIDER, R.J., and WEINSTEIN, B.M. (2002). Disruption of acvrl1 increases endothelial cell number in zebrafish cranial vessels. Development 129: 3009-3019.

ROTHMAN, A., KULIK, T.J., TAUBMAN, M.B., BERK, B.C., SMITH, C.W.J., and NADAL-GINARD, B. (1992). Development and characterization of a cloned rat pulmonary arterial smooth muscle cell line that maintains differentiated properties through multiple subcultures. Circulation 86: 1977-1986.

SCOTT, I.C., MASRI, B., D'AMICO, L.A., JIN, S.-W., JUNGBLUT, B., WEHMAN, A.M., BAIER, H., AUDIGIER, Y., and STAINIER, D.Y.R. (2007). The G proteincoupled receptor Agtr1b regulates early development of myocardial progenitors. Dev. Cel/12: 403-413.

SHORE, P. and SHARROCKS, A.D. (1995). The MADS-box family of transcription factors. Eur. J. Biochem. 229: 1-13.

SPENCER, J.A. and MISRA, R.P. (1996). Expression of the serum response factor gene is regulated by serum response factor binding sites. J. Biol. Chem. 271: 16535-16543.

STREB, J.W. and MIANO, J.M. (2005). AKAP12 $\alpha$ : an atypical serum response 
factor-dependent target gene. J. Biol. Chem. 280: 4125-4134.

SUN, Q., CHEN, G., STREB, J.W., LONG, X., YANG, Y., STOECKERT, C.J., JR., and MIANO, J.M. (2006). Defining the mammalian CArGome. Genome Res. 16: 197-207.

VOGEL, A.M. and GERSTER, T. (1999). A zebrafish homolog of the serum response factor gene is highly expressed in differentiating embryonic myocytes. Mech. Dev. 81: 217-221.

WALLACE, K.N., AKHTER, S., SMITH, E.M., LORENT, K., and PACK, M. (2005). Intestinal growth and differentiation in zebrafish. Mech. Dev. 122: 157-173.

WANG, D.-Z., CHANG, P.S., WANG, Z., SUTHERLAND, L., RICHARDSON, J.A., SMALL, E., KRIEG, P.A., and OLSON, E.N. (2001). Activation of cardiac gene expression by myocardin, a transcriptional cofactor for serum response factor. Cel/ 105: 851-862.

WANG, Z., WANG, D.-Z., HOCKEMEYER, D., MCNALLY, J., NORDHEIM, A., and OLSON, E.N. (2004). Myocardin and ternary complex factors compete for SRF to control smooth muscle gene expression. Nature 428: 185-189.
WANG, Z., WANG, D.-Z., PIPES, G.C.T., and OLSON, E.N. (2003). Myocardin is a master regulator of smooth muscle gene expression. Proc. Nat/. Acad. SCI., USA 100: 7129-7134.

YANG, X., YAO, J., CHENG, L., WEI, D., XUE, J., and LU, D. (2003). Molecular cloning and expression of a smooth muscle-specific gene SM22 $\alpha$ in zebrafish. Biochem. Biophys. Res. Comm. 312: 741-746.

YOSHIDA, T., SINHA, S., DANDRE, F., WAMHOFF, B.R., HOOFNAGLE, M.H., KREMER, B.E., WANG, D.-Z., OLSON, E.N., and OWENS, G.K. (2003) Myocardin is a key regulator of CArG-dependent transcription of multiple smooth muscle marker genes. Circ. Res. 92: 856-864.

ZAROMYTIDOU, A.-I., MIRALLES, F., and TREISMAN, R. (2006). MAL and ternary complex factor use different mechanisms to contact a common surface on the serum response factor DNA-binding domain. Mol. Cell. Biol. 26: 4134-4148.

ZHANG, S.X., GRAS, E.G., WYCUFF, D.R., MARRIOT, S.J., KADEER, N., YU, W., OLSON, E.N., GARRY, D.J., PARMACEK, M.S., and SCHWARTZ, R.J. (2005). Identification of direct serum response factor gene targets during DMSO induced P19 cardiac cell differentiation. J. Biol. Chem. 280: 19115-19126.

\section{Related, previously published Int. J. Dev. Biol. articles}

See our recent Special Issue Ear Development edited by Bernd Fritzsch and Fernando Giraldez at: http://www.ijdb.ehu.es/web/contents.php?vol=51\&issue=6-7

See our Special Issue Stem Cells \& Transgenesis in honor of Ralph Brinster and edited by Robert E. Hammer and Richard R. Behringer at: http://www.ijdb.ehu.es/web/contents.php?vol=42\&issue $=7$

Expression of protocadherin 18 in the CNS and pharyngeal arches of zebrafish embryos

Fumitaka Kubota, Tohru Murakami, Yuki Tajika and Hiroshi Yorifuji

Int. J. Dev. Biol. (2008) 52: 2424-2424

Embryonic heat shock reveals latent hsp90 translation in zebrafish (Danio rerio)

Michelle H. Connolly and Brian K. Hall

Int. J. Dev. Biol. (2008) 52: 71-79

The retinoic acid metabolising gene, CYP26B1, patterns the cartilaginous cranial neural crest in zebrafish Susan Reijntjes, Adam Rodaway and Malcolm Maden

Int. J. Dev. Biol. (2007) 51: 351-360

Pax7 identifies neural crest, chromatophore lineages and pigment stem cells during zebrafish development

Ana M Lacosta, Jesús Canudas, Cristina González, Pedro Muniesa, Manuel Sarasa and Luis Domínguez

Int. J. Dev. Biol. (2007) 51: 327-331

Spatiotemporal expression of the creatine metabolism related genes agat, gamt and ct 1 during zebrafish embryogenesis

Lifeng Wang, Ying Zhang, Ming Shao and Hongwei Zhang

Int. J. Dev. Biol. (2007) 51: 247-253

Zebrafish spata2 is expressed at early developmental stages

Enrico Moro, Claudio Maran, M. Liliana Slongo, Francesco Argenton, Stefano Toppo and Maurizio Onisto

Int. J. Dev. Biol. (2007) 51: 241-246

Cadherin- 6 is required for zebrafish nephrogenesis during early development Fumitaka Kubota, Tohru Murakami, Kenji Mogi and Hiroshi Yorifuji Int. J. Dev. Biol. (2007) 51: 123-129

2006 ISI **Impact Factor $=3.577^{* *}$

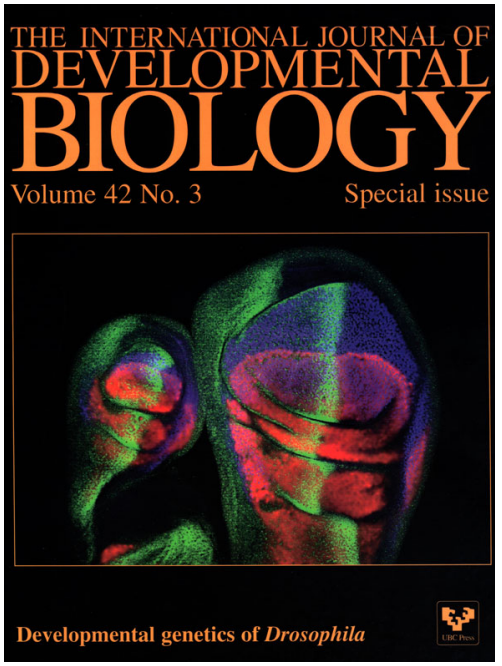

